\title{
OP-161根治手術の施行された上部尿路上皮癌の 術後予後因子の检討
}

\begin{abstract}
東京医科大学医学部泌尿器科学講座
橋本 剛, 大野 芳正, 中島 淳, 権藤 立男, 濱田 理宇, 小津 兆一郎, 並木 一典, 堀口 裕, 吉岡 邦彦,

大堀 理, 秦野 直, 橘 政昭

目的：根治手術が施行された原発性上部尿路上皮癌の中で 予後に影響を与える臨床病理学的因子について検討した。 方法：2000 年から 2007 年までに根治手術の施行された原 発性尿路上皮癌のうち術前後の補助化学療法が施行された 症例を除いた $\mathrm{pTa}$ から T4 までの 50 例を対象とした。男 性 37 例、女性 13 例、平均年齢 69 歳 (46-85) であった。 観察期間の中央值は 22.5 ケ 月(4ヶ月一 94 ケ月)であった。 病理学的因子、年齢、性別、腫瘍占拠部位について子後と の関連を検討した。生存率の算出は kaplan-meier 法を用 い、予後因子の検討は $\operatorname{cox}$ 比例ハザードモデルによる多変 量解析を行った。結果：単変量解析では病理学的因子につ

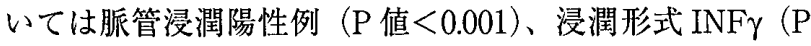
值 $<0.001$ )、細胞異型度が G3 症例、深達度が $\mathrm{pT} 3$ 以上の症 例ならびに剥離断端陽性例はそうでない症例に比べ有意に 予後が不良であった。また多変量解析においては脈管浸潤 陽性、剥離面断端陽性、浸潤形態 INF $\gamma$ が独立した予後不良 因子であった。結語：根治的手術の施行された原発性上部 尿路癌において脈管浸潤の有無、INF $\gamma$ 、剥離断端の癌の有 無、浸潤形態が予後因子であると示唆された。
\end{abstract}

\section{OP-162 当院で経験した腎孟尿管癌の臨床的な検 討}

\section{倉敷中央病院病院泌尿器科 \\ 公平 直樹, 北 悠希, 牧野 雄樹, 田岡 利宜也, \\ 宗田 武, 井上 幸治, 武縄 淳, 寺井 章人}

1993 年 3 月より 2007 年 11 月までに上部尿路癌に対して 205 例 の腎尿管摘出術を施行。その中で術前化学療法を施行した症例 やリンパ節転移が確認された症例、広範なリンパ節郭清した症 例は除外した。術前画像検查や術中所見でリンパ節腫大が確認 された場合にはサンプリング目的で摘出しているが基本的には 広範なリンパ節郭清はしていない。術前術後の表在性膀胱腫汮 を治療した症例は含めたが、浸潤性膀胱癌と診断加療された症 例は除外した。(結果) 上記内容に適合するもの 152 例，男/女： $105 / 47$, 平均年齢 71.3 歳。腎孟/尿管 : $84 / 68$, 開腹/後腹膜鏡補助 下 : 66/86, G1-2/G3:84/68, 病期 ; cis : 5/a : 47/T1 :29/T2:27/ $\mathrm{T} 3$ : 44 例。壁内脈管浸潤なし: 98 例、 $\mathrm{ly}+22$ 例、 $\mathrm{v}+8$ 例、 ly + $\mathrm{v}+24$ 例。それぞれにおいて解析すると、腎孟尿管部位別、Grade 別、病期別、壁内浸潤有無において有意差を認めた。さらに腎孟 尿管に分類して 5 年生存率 (\%) を比較すると、腎孟/尿管、cis・ a :96/79、T1 : 100/100、T2:100/57、T3:61/38。腎孟/尿管。壁内 脈管浸潤なし:96/84、ly+: 100/54、v+：100/26、ly+v+： $31 / 26$ だった。(考察)部位により予後が左右される可能性が示さ れた。それは壁内浸潤が起こりやすいかどうかが起因している と考えられた。腫瘍部位を明確にして病理診断を詳細にするこ とで、追加治療の必要性を判別することができると思われる。

\section{OP-163当科における BCG 上部尿路灌流療法の 治療成績}

\section{弘前大学大学院医学研究科泌尿器科学講座}

米山高弘, 山本 勇人, 岡本 亜希子, 今井 篤,

畠山 真吾, 岩㴊 郁哉, 橋本 安弘, 百瀬 昭志,

盛 和行, 古家 琢也, 神村 典孝, 大山 力

レトロスペクティブに上部尿路上皮内癌に対する $\mathrm{BCG}$ 上部尿路灌 流療法の治療成績を検討した。1997年 12 月より 2008 年 7 月までに BCG 上部尿路灌流療法を施行.した 18 例 (男性 14 例, 女性 4 例)を対 象とした. 全尿路上皮内癌 6 例, 雨側上部尿路上皮内癌 6 例, 片側上 部尿路上皮内癌 6 例であった，平均観察期間 46.4 ヶ月 (3-126), 平 均年齢 72.8 才 $(55-90)$ であった. Double-Jカテーテルを使用し上 部尿路を灌流した例が 12 例, Single-J カテーテルを使用した例が 5 例，疗管皮痛万うより灌流を行った例が1例であった。週一回，計 6 週施行した. 初期の 4 例は $80 \mathrm{mg}$ にて灌流し，以後は $40 \mathrm{mg}$ にて灌流 を行った. 治療効果の判定は尿細胞診で行った. 18 例中 15 例で尿細 胞診が陰性化した (83.3\%). BCG 灌流療法が有効であった 15 例の 内， 2 例が上部尿路に再発した. 残りの 13 例は平均 38.0 ケ月間 (3126）再発を認めていない. BCG 上部尿路灌流療法が無効であった 3 例の内， 2 例は後治療を拒否，1例は他因子した，また，副作用によ り，4例が治療完遂できなかった．副作用は 18 例中 17 例 $(94.4 \%)$ に 認められた．膀胱刺激症状が最も多く，腎結核も2例に認められた。 観察期間中， 2 例が癌死した. 上部尿路上皮内癌に対する $\mathrm{BCG}$ 上部 尿路灌流療法は有効であるが，高度な副作用の出現の可能性がある ため，注意深く観察する必要があると思われた。

\section{OP-164 進行性尿路上皮癌に対する低漕度抗癌昘 併用局所ハイパーサーミアの効果}

名古屋前立腺センター"，同志社大生命医科学部22，厚生 連海南病院 ${ }^{3)}$

上田 公介 ${ }^{11}$, 長谷川 武夫 ${ }^{2)}$, 山田 泰之 ${ }^{3 \prime}$

はじめに：進行性尿路上皮癌に対しては全身化学療法とし て M-VAC 療法がおこなわれているが、副作用が強く、完 遂率が低く、また治療効果は一時的なものであり、長期生 存がえられていない。そこで当科では副作用が少なく、長 期生存がえられる低濃度抗癌剂併用局所ハイパーサーミア を開発し、治療をおこなってきたので、その治療効果につ いて報告する。対象と方法：対象は当科を受診した進行性 尿路上皮癌患者 5 名である。 4 例は膀胱癌、 1 例が腎盂癌で ある。治療方法は抗癌㓮として CDDP, MMC, ジェムザー ルなどを使用し、ハイパーサーミア前に生食水 $500 \mathrm{ml}$ に CDDP2.5-10mg, MMC10mg, ジェムザール 200mgをそれ ぞれ溶解し、静脈内に点滴投与した。ハイパーサーミアは 一回 30-50 分加温した。これを一症例に対して 5-10回おこ なった。結果と考察：結果は 5 例中 3 例に CR がえられ、 1 例が PR, 1 例が NC であった。 1 例が他病死、 4 例が生存し ている(生存期間は 3 年から 5 年)。副作用は軽い疲労感が あるのみで重篤なものはみられていない。以上より当科で 扔こなっている低濃度抗癌㓮併用ハイパーサーミアは副作 用が少なく、長期生存がえられるだけでなく、治療効果に 優れた方法と考えられた。 